\title{
ARE GREEK SPECIAL EDUCATION TEACHERS IN FAVOUR OF THE INCLUSION OF PUPILS WITH INTELLECTUAL DISABILITY? AN ONLINE SURVEY
}

\author{
Christina S. Lappa ${ }^{1 \mathrm{i}}$, \\ Constantinos N. Mantzikos ${ }^{2}$ \\ ${ }^{1}$ Post Doc, PhD, MSc. \\ Hellenic Open University, \\ Patras, Greece, \\ Department of Special Education, \\ University of Thessaly, \\ Volos, Greece \\ ${ }^{2}$ Special Education Teacher, \\ Greek Ministry of Education and Religious Affairs \\ $11^{\text {th }}$ Kindergarten of Larissa, \\ Greece
}

\begin{abstract}
:
Few studies have been conducted in Greece focusing on the inclusion of pupils with Intellectual Disability (ID) in general classes. The aim of this quantitative study was to explore the attitudes of Special Education Teachers (SETs or SET) towards the inclusion of pupils with ID in general classes. A structured questionnaire was sent out. It consisted of 10 demographic questions and of 6 structured closed-ended questions about the inclusion of this group of pupils in general classes, using a 5-point Likert scale. The study sample consisted of 150 SETs [129 (86\%) females and $21(14 \%)$ males]. The questionnaire data were analysed via descriptive and inferential statistics (SPSS version 21). The results of the research showed that the majority of SETs had a positive attitude towards the fact that the special and general education teacher should jointly adapt the classroom according to the needs of the pupil with ID and that inclusive education is appropriate for these pupils. The SETs had a neutral to positive attitude about whether pupils with ID should be educated in general settings with pupils without disabilities and whether they should be removed less frequently from general education settings in order to be given more help with their difficulties. Finally, there were some dependent variables that played a major role in participants' responses, such as education, work experience, work and the structure of employment. In conclusion, SETs point out that they are in favour of the inclusion of pupils with ID. Finally, the results of the study are discussed.
\end{abstract}

Keywords: special education teachers, Greece, inclusion, attitudes, intellectual disability

i Correspondence email: xlap@uth.gr 


\section{Introduction}

Attitudes, knowledge and perceptions about the education of children with special educational needs and disabilities (SEND) have changed profoundly over recent years. There has been a major shift from educating children with SEND in a segregated environment towards increasingly including them in general classes (Hastings \& Oakford, 2003; O'Leary, Henderson, Jacobs \& Cooper, 2016). That is why in recent decades inclusive education has been a recurring theme in educational reforms (Civitillo, De Moor \& Vervloed, 2016).

Inclusive education is a timely issue that concerns many researchers both in Greece and abroad. It constitutes a new impetus for the development of today's school. In fact, it is an applied policy, a philosophy of pioneering change in its broadest sense. It can be viewed as a dynamic and ongoing process of organisational and pedagogical reorganisation. Its main goal is to prevent student segregation and isolation by embracing diversity and advocating for a common curriculum for all pupils based on various fundamental principles, such as equal opportunities, educational equity, and social justice (Gallego-Ortega \& Rodríguez-Fuentes, 2021, p. 2). Ainscow (2005) defines inclusive education as a process whose main objective is the inclusion of all pupils with SEND in school in order to have learning outcomes and conditions to further their social development. In practice, inclusion means teaching in heterogeneous classes in which pupils with varying individual needs exist (Takala, Pirttimaa \& Törmänen, 2009). It is about the active presence, meaningful participation and acceptance of the pupil with SEND in a general education classroom (Humphrey \& Lewis, 2008). It ensures a feeling of 'belonging' and the shared responsibility of teachers for all pupils in the school (Takala et al., 2009). Proper functioning of inclusion means accepting diversity and removing exclusion at all levels (social, economic, academic, racial, gender, etc.) (Slee, 2011), adapting teaching (pedagogical methods) and curriculum, teacher collaboration, and support from the headmaster/director of the school (Takala et al., 2009). It is, therefore, according to Stasinos (2016, p. 59) "the design of a curriculum and an organisational strategy in mainstream schools that respond to the full spectrum of pupil diversity and diversity as a whole". In short, the term "inclusion" refers not only to the placement of a child with SEND in the regular school, but also to the conditions under which all children can be effectively educated (Angelides, Stylianou \& Gibbs, 2006). Soulis (2008) correctly states that inclusion is not just a personal matter of SETs in the general school, thereby relieving the general education teacher of responsibility for its implementation. Inclusion can only be realised and achieved when all stakeholders are involved. For this reason, teachers are required to create learning environments that encourage the use of practices to empower these pupils. Consistent inclusion requires teachers with high levels of self-efficacy (Slee, 2010) and positivity around accepting children identified with special educational needs (Pantic \& Florian, 2015). Teacher cooperation is essential. Hughes and Murawski (2001) consider that collaboration means interaction between at least two teachers with different 
specialisations and includes dialogue, planning, shared and creative decision-making, as well as feedback aimed at providing appropriate services to pupils.

There is a widespread belief that the effectiveness of inclusion is dependent on the role of teachers. Teachers are regarded as one of the most important factors in promoting or obstructing inclusion processes. Both general and special educators are the primary agents responsible for creating less restricted environments in their classrooms. Their beliefs will be defining for the classroom behaviours observed, as these conceptions have a huge influence on theirs attitudes and inclusive practices when it comes to meeting the needs of pupils with SEND (Jordan, 2018, as cited in Gallego-Ortega \& RodríguezFuentes, 2021). Attitude is defined as a person's proclivity to think (cognitive component i.e. thoughts, knowledge and beliefs about the attitude object), feel (affective component, i.e., feelings toward the attitude object), and behave (behavioural component, i.e., intended behaviour toward the attitude object) in certain ways toward certain defined targets (Arnold, Silvester, Patterson, Robertson, Cooper \& Burnes, 2005; Krischler \& Pitten Cate, 2019). Attitudes toward inclusion among teachers were found to be related to specific types of disability (Avramidis, Bayliss, \& Burden 2000a), experience with inclusive education (Avramidis \& Norwich, 2002), and class size (Moberg, 2003).

According to Avramidis, Bayliss and Burden (2000b) teacher attitudes can act either to facilitate or limit the implementation of policies. The success of innovative and demanding programming depends on the cooperation and commitment of those who are directly involved. Teacher attitude is a variable that can positively or negatively affect the implementation of an inclusion programme and educational practice; that is the teaching interventions that teachers will choose for children, whether they are to be successful and effective (de Boer, Pijl \& Minnaert, 2011), as well as the teaching goals of their educational interventions (Padeliadu et al., 1998, p. 14, as cited in Mavropoulou \& Padeliadu, 2000).

The findings of studies on teachers' attitudes on inclusion have revealed a perplexing picture (de Boer et al., 2011). Teacher's positive attitudes and expectations are critical for successful inclusion (de Boer et al., 2011), and especially for the outcomes of pupils with SEND (Male, 2011). Also, teachers who have a positive attitude toward inclusion are more willing to modify their approaches in order to benefit all learners with a variety of learning needs (Subban \& Sharma, 2006). While the majority appears to support inclusive education (Rose, 2001), there are teachers who do not want to be involved in inclusive education in their own teaching practice (Anderson, Klassen, \& Georgiou, 2007). Also, a study by Hettiarachchi and Das (2014) revealed that diversity in school and classroom populations may induce higher stress levels in mainstream teachers.

Inclusion also applies to pupils with ID, and the benefits are many and lasting, especially with regard to the social benefits of interacting with classmates within the general classroom. ID is a condition with reduced or incomplete development, which does not allow the person to keep up with the social environment (Luckasson, BorthwickDuffy, Buntinx, Coulter, Craig, \& Reeve 2002). According to the American Association of 
Intellectual and Developmental Disability, ID is characterised by significant constraints in both intellectual function and adaptive behaviour which is manifested in conceptual, social and practical adaptive skills. It is diagnosed before the age of 22 (AAIDD, n.d.; Schalock, Luckasson, \& Tassé, 2021). ID is determined by individual standard assessment providing ratings below 70 (100 being the population average), and the impaired ability to adapt to the demands of normal life. ID affects about 1 to 3 percent of the population (Luckasson et al., 2002).

Given the literature's general agreement that the success of policies of inclusion, acceptance, and accommodation of pupils with ID in general education settings is dependent on teachers' attitudes (Varcoe \& Boyle, 2014), and that inclusion can only be achieved if teachers are supported in developing all aspects of knowing, doing, and believing (Loreman, Sharma, \& Forlin 2013), an understanding of their attitudes toward the concept and process of inclusion appears critical (e.g., Khochen \& Radford, 2012; Lappa \& Mantzikos, 2018).

\section{The Greek context}

In Greece, there are a number of laws and presidential decrees which were introduced to determine how to educate pupils with SEND in special and general education classrooms. Article 1 of the first such piece of legislation, Law 1143/1981, defines the student population, the intentions of the special education provided and the principles for the establishment of the study structures. The goal of this law is to provide special education and specialised vocational training to people who deviate from what is considered normal, as well as to introduce social measures and promote their subsequent integration into social life and professional productivity, by implementing specific educational programmes in conjunction with medical and other social issues.

In the mid-1980s, Law 1566/1985 was introduced, which continued more or less in the same manner as the aforementioned law. In 2000, Law 2817 introduced the operation of KEDDY (Greek Public Diagnostic and Assessment Centres for the Support of Special Educational Needs) at the headquarters of each prefecture. In addition, pupils with SEND can attend a general education class while receiving parallel support (in-class support) or in a specially organised and staffed integration class which functions in the mainstream education setting and is provided by a SET. The SET may help these pupils in some or all courses depending on their needs (Sarris, Riga \& Zaragas, 2018). Finally, in the same line as the previous law is the Law 3699/2008 on Special Education (Deropoulou-Derou, 2012).

Based on this law, pupils with SEND may attend general education classes (Parallel Support or Integration Class) based on the judgement and written declaration of the KEDDY [later called Educational and Counseling Support Centres (KESY) and now Counseling and Support Evaluation Diagnostic Centres (KEDASY)]. Moreover, in providing general education classes a basic criterion is the type as well as the degree of disability of the student, with priority being given to those who are blind or diagnosed 
with Autistic Spectrum Condition (Drakotou \& Zoniou-Sideri, 2016; Kontoleon \& Deropoulou-Derou, 2013; Lampadari \& Garavelas, 2018; Novakos, 2018).

The aim of integration classes was redefined by Law 4368/2016 (Article 82) (Government Gazette 21/A/2016) in order to prevent learners from being discriminated against because they were pulled out of mainstream classes to attend integration classes. The fundamental goal of integration courses, according to Law 4368/2016, is for children with SEND to be fully integrated into the classroom environment. In this environment, integration classroom instructors, in collaboration with class teachers, provide help to pupils in mainstream classrooms. They differentiate activities and teaching procedures while also adapting educational materials and environments. Only on a rare occasion is one-on-one assistance provided in a separate integration classroom. The main goal of instructional intervention in this scenario is the pupil's future full inclusion in the mainstream class. The majority of learners with SEND have their needs met in these types of mainstream settings. When it becomes extremely challenging for children with SEND to attend mainstream schools or integration courses due to their needs, they:

1) attend special education schools;

2) attend schools or departments that operate as self-contained units or annexes of other schools within certain hospitals, rehabilitation units, juvenile detention centres, and chronic disease centres that cover children with SEND; and

3) if they are unable to attend school due to short- or long-term health issues, they can get tuition at home (see also: Warren, Soukakou, Foster, $\mathrm{Ng}$, \& DeropoulouDerou, 2021).

KEDASY competencies include making appropriate school-setting recommendations. When picking a school for their child, parents take this into account. A number of different policies have been implemented to address the requirements of disabled pupils and promote their educational inclusion. These are some of them:

1) free assessment and counselling services;

2) the provision and implementation of Individual Education Plans (Article 6(5));

3) the provision of one-to-one school nurses (4186/2013, Article 28(18), Circular 91409/A3/3-6-2016) and special support staff (Law 3699/2013, Article 18(1) and (2), as amended by article 56 of Law 3966/2011, and Circular, issued by the Deputy Minister No. 90911/A3/9-6-2015);

4) co-educational programmes between mainstream and special schools (Article 82 (3)(a) of Law 4368/2016), which aim to raise awareness and close the gap between special and mainstream schools;

5) relevant in-service training for teachers and other participants, with a particular focus on issues of differentiation and accessibility; and accessible educational and instructional materials (European Agency for Special Needs and Inclusive Education, 2021).

As a result, educational policies have evolved into real vectors for the development of positive communities that contribute to the creation of an inclusive 
society (Batarelo et al., 2016; Clipa \& Greciuc, 2018; Monsenet al., 2014; Unianu, 2012, 2013, as cited in Mata \& Clipa, 2020).

\subsection{Literature review on the attitudes of teachers toward inclusion of individuals with ID}

This literature review is based on the search of the well-known international databases (e.g., ERIC, Scinpase, PubMed, ScienceDirect, etc) for sources related to this topic.

\subsubsection{The attitudes of general education teachers toward inclusion of individuals with ID}

Several studies conducted in a variety of countries revealed varying attitudes of general educators toward inclusion. A large number of studies have been conducted to investigate teachers' attitudes toward the inclusion of pupils with ID in general educational settings (Takala et al., 2009).

Ojok and Wormnæs (2013) examined the attitudes of 125 school teachers from Karamoja in north-eastern Uganda. They used the Opinions Relative to Mainstreaming Scale (ORMS), developed by Larrive and Cook (1979). The findings showed that teachers had slightly more positive than negative attitudes. They also feel more willing to teach pupils with ID. One more finding showed that the attendance of teachers at various workshops and seminars has a positive impact on their attitudes and willingness towards the inclusive education of these pupils.

Memisevic and Hodzic (2011) examined the attitudes of teachers of a Bosnian Primary School to the inclusion of pupils with ID in general classes. The findings of their research showed that the majority of the Bosnian educators in the study expressed their support for the inclusion of pupils with ID. However, teachers also expressed their fears and concerns about the availability of appropriate training for teachers to support mentally disabled pupils in the general education classroom. Meanwhile, teachers who had experience teaching lower elementary pupils tended to have more supportive prospects for the inclusion of pupils with ID than those teachers who had experience teaching higher elementary pupils.

Hastings and Oakford (2003) used the Impact of Inclusion Questionnaire to look at pre-service trainee teachers' attitudes towards including pupils with ID, emotional and behavioural difficulties. The participants showed more positive attitudes towards the inclusion of pupils with ID and more negative attitudes towards the inclusion of pupils with emotional and behavioural difficulties. The concerns of pre-service trainee teachers had to do with the negative impact of the inclusion of pupils with emotional and behavioural difficulties on their peers, teachers and the general school environment.

Alghazo and Naggar Gaad (2004) conducted a survey with a questionnaire that consisted of a series of structured interviews to explore the prospects of teachers from the United Arab Emirates about inclusive education of children with SEND in general education schools. According to the findings of their study, teachers have negative attitudes toward the inclusion of pupils with ID in general education classes. In 
particular, teachers were more opposed to inclusive education for pupils with severe ID, while male teachers showed even more negative perceptions compared to female teachers. Another important finding was that teachers who had five years of teaching experience showed greater acceptance towards including this group of pupils in their classrooms.

\subsubsection{The attitudes of special and general education teachers toward inclusion of individuals with ID}

Arcangeli, Bacherini, Gaggioli, Sannipoli and Balboni (2020) examined the attitudes of teachers toward ID using the ATTID questionnaire. Their study sample was 307 mainstream teachers and 237 SETs from Italy. They revealed that the SETs group held more positive attitudes. A very interesting finding is that this group of teachers had higher levels of perceived efficacy of ID knowledge, showed less discomfort and were more willing to interact with individuals with ID. But mainstream teachers showed that they have a greater knowledge of the capacity and rights of these disabled individuals.

Vernier (2012) explored the impact of an in-service training programme on the attitudes of special and general education teachers, comparing the changes in the prospects of both the special and general education teachers before and after the programme was drawn up. While analysis of the post-test data showed an improvement in the attitudes of both teacher groups, SETs had higher pre-test values/rates for positive prospects for the inclusion of pupils with ID than general education teachers. The study appears to attribute this difference to pre-test responses to the possibility that SETs have had prior previous training in inclusive education in the form of a required course of study which must be completed in order to obtain the license to practise as a special educator. However, her research did not show the relationship between teachers' attitudes and other variables that were collected, such as years of teaching experience and teaching levels.

Multiple studies, on the other hand, reported teachers' negative attitudes toward inclusion. A survey by Anagnostopoulou and Deropoulou-Derou (2012) studied the attitudes of teachers (preschool, primary, and junior high school) about ID. Their sample was comprised of 103 teachers from the general overall educational district of Piraeus in Greece and teach in general education classes, special classes, and integration classes. The results of their research showed that teachers often refused to include pupils with physical disabilities, pupils with learning disabilities and pupils with Greek as a second language, while intellectual, sensory disabilities and disorders related to behavioural problems were to be avoided to a significant extent.

Alquraini (2012) conducted a survey in Saudi Arabia and studied the attitudes of general education teachers and SETs for the inclusion of pupils with severe ID in general education classes. The researcher concluded that teachers had comparatively negative attitudes towards the inclusion of seriously disabled pupils in general education state schools. Teachers who had previous educational experience with pupils with SEND, however, showed fewer negative attitudes towards inclusion of pupils with severe ID. 
Finally, the results of his research showed that teachers working in large-size classes showed more negative attitudes and more concerns about the inclusion of pupils with severe ID.

\subsection{The purpose of the study}

The present study, examines the attitudes of SETs towards the inclusion of pupils with ID in general education classes. The present study pursued the following objectives:

- To study the attitudes of SETs towards the inclusion of pupils with ID in general education classes.

- To study whether the attitudes of SETs to the education of this group of pupils are positive, negative or neutral.

- To study whether SETs will have a positive, negative or neutral attitude towards the inclusion of pupils with ID and whether they should modify the classroom according to the needs of these pupils.

- To study whether SETs will have a positive, negative or neutral attitude towards the fact that pupils with ID could be more effectively trained in general education settings.

\section{Methodology of the study}

\subsection{Research hypotheses}

Based on the preceding review of the relevant literature, the researchers formulated the following research hypotheses:

Hypothesis 1: It is expected that SETs will have ambiguous attitudes towards the education of individuals with ID.

Hypothesis 2: It is expected that SETs will not have a positive attitude towards the inclusive education of pupils with ID and that they would want to modify the classroom according to the needs of these pupils.

Hypothesis 3: SETs are expected to have a cautious attitude towards the fact that pupils with ID can be more effectively trained in general education settings.

\subsection{Sample}

The final sample consisted of 150 SETs. The characteristics of the SETs comprising the sample were as follows:

The gender distribution was $86 \%$ women, $14 \%$ men. In terms of age, $47.3 \%$ were aged 26 to $35.28 .7 \%$ were aged 22 to 25 , followed by $19.3 \%$ aged 36 to 45 . The 46 to 55 age bracket accounted for $4.7 \%$. With reference to length of service, the 0-5 years option accounted for the highest percentage of responses (66\%) followed by the 6-10 years option with $22 \%$, the $11-15$ year option with $6.7 \%$, the $16-20$ years option with $4 \%$ and the more than 20 years option with just 1.3\%. 61.3\% of individuals in the sample said they were primary school teachers and $38.7 \%$ said they were secondary school teachers. $48.7 \%$ declared they had a postgraduate qualification in special education, while $4 \%$ said they 
had a postgraduate qualification in school psychology. 33.3\% said they had an undergraduate degree in special education, $13.3 \%$ had attended seminars in special education lasting 250 to 600 hours and 0,7\% had attended a two-year academy. Asked whether they were working during the current school year (2017-2018), 78\% responded in the affirmative. $22.7 \%$ declared they worked in parallel support (in-class support), $18 \%$ worked in integration classes and $18.7 \%$ in special schools. $14.7 \%$ declared they worked in a private educational/therapeutic setting and $4 \%$ said they worked for KEDASY, while $22 \%$ were not yet in work. Asked about how many years the teachers had had pupils with ID in their classroom, the majority $86 \%$ responded 0 to 5 years, $12.7 \%$ chose the next option (6 to 10 years), $0,7 \%$ said 11 to 20 years and $0,7 \%$ said 20 years plus. With respect to the number of pupils with ID in the classroom in the last 2 school years, it was clear that the average number of pupils for the year 2016-2017 was 1.29 and for 2017-2018 was 1.30 .

\subsection{Data collection tool-Process}

According to Avramidis and Kalyva (2006), a research tool should always be developed based on the research questions or the research hypotheses posed by the researchers, as well as the types of data, in order for the questions to be answered in the context of their research. However, the same authors go on to say that researchers can also use questionnaires that are based on the literature, or can develop their own research questionnaire, or can employ a combination of both. In addition, they mention that researchers who adopt an existing questionnaire can supplement it with their own questions.

In this specific case, the researchers relied on both Greek and international bibliography, to find questions relevant to their topic. The researchers relied on the philosophy that underpins the questions in the survey developed by Cullen, Gregory, and Noto (2010) "Teacher Attitudes Toward Inclusion Scale, TATIS", since it was considered suitable for developing their own questionnaire. That specific questionnaire has been used in quite a few studies. More specifically, it was used by Wilkerson (2012), in her doctoral thesis, to assess the attitudes of teachers towards inclusion of pupils with autism, by Yunkis (2015) to study the attitudes of pre-service teachers towards inclusion of deaf pupils, by Pervin (2016), in her master's dissertation, to explore the attitudes of general education teachers towards inclusion of pupils with autism, and by Sharma and Nuttal (2016) to investigate the impact of training on the attitudes, concerns and effectiveness of pre-service teachers in implementing inclusion. The questions were chosen in order to quantitatively examine the attitudes and stances of SETs about the inclusion of pupils with ID in general classes.

The questionnaire was generated using Google Forms. 10 questions about demographic details were used as well as 6 structured questions which examined attitudes about the inclusion of children with ID into general education classes. Closedended, 5-step Likert scale items were used, where 1 corresponded to Strongly disagree, and 5 to Strongly agree, with 3 representing the median in the scale and corresponding 
to the option Neither agree nor disagree. Before sending the research tool, the researchers conducted a pilot study on six teachers to determine possible difficulties or ambiguities in the wording of the statements

The researchers gathered all the information about the schools from the personal website of the special education school advisor. They found all the e-mails of schools which are located in Larissa, Karditsa, Trikala and Magnesia (Greece). The total number is 176 general and special primary and secondary education schools. In the second phase, they sent the questionnaire to all these schools by e-mail.

The authors considered that data collected using social media is an important solution because it has many advantages. The international literature mentions the advantages and disadvantages of this methodology (e.g., Boyer, Olson \& Jackson, 2001; Fricker \& Schonlau, 2002; Medlin, Subroto \& Theong, 2005; Metha \& Sivadas, 1995; Van Selm \& Janovski, 2006; Wright, 2005; Zhang, 1999). The reason that they used this methodology is that teachers use the internet and social media in their daily lives (i.e., Facebook or Gmail) (Kamtsios \& Lolis, 2016). On the other hand, there are many surveys which have been done with this methodology (see the references: Garrad, Rayner, \& Pedersen, 2018; Kamtsios \& Lolis, 2016; Lappa, Mantzikos \& Paraskevopoulos, 2019; Parsons, 2014; Parsons \& Lewis, 2010; Parsons, Lewis \& Ellins, 2009; Winter \& Bunn, 2019). So, they sent it to general and special education teachers' associations, the association of graduates of special education departments and to groups of SETs on the social media and they sent it as a personal message (on Facebook) to special and general education teachers. The survey was conducted between September 2017 and June 2018 .

Participants were informed about the topic, the structure of the research tool and the time they would need to spend on the survey. The code of conduct on confidentiality and anonymity was followed. Participation in the study was voluntary, meaning that only those who filled out the entire questionnaire were included in the sample.

\subsection{Reliability of the data collection tool}

Examining the reliability of the questions, given that the Cronbach's Alpha internal consistency value is above 0.6 , the tool is considered to be very reliable. The Cronbach's Alpha reliability value is high at 0.750 . Consequently, all questions have been answered reliably.

\subsection{Data analysis}

The data in the sample was analysed using SPSS version 21 (Statistical Package for the Social Sciences). Initially a descriptive statistical analysis was performed. Then the dependence of the questionnaire's variables on the demographic characteristics of the survey sample was tested (statistical inference). Given the sample's large size, this related to checking the average values and was done using a t-test for independent samples in subgroups generated using the variables of demographic and general characteristics of the individuals in the sample where there were 2 subgroups, and by carrying out an ANOVA analysis of variance in the case of more than 2 subgroups. To examine the 
existence of a correlation between the evaluation of the statements and the number of pupils with ID per year, a correlation test was carried out. The presentation of the descriptive measures and the test of dependence on the demographic characteristics are shown per group of questions comprising the survey tool. The significance value used is $\mathrm{p}=0.05$.

\section{Results}

Although the analysis of the questionnaire data shows that $41.3 \%$ of SETs hold a neutral attitude on whether the education of pupils with ID is better in general classes rather than in special classes, it is remarkable that a large percentage $(65.4 \%)$ believes that inclusive education is the most suitable for these pupils and $66.7 \%$ believe that inclusion can be achieved for these pupils, even though they are lacking in some areas of their development. Also, $75.3 \%$ of SETs have a positive attitude towards the need to modify the classroom taking into account the needs of pupils with ID.

On the other hand, there are issues on which some SETs hold a neutral and others a positive attitude. In particular, $34.7 \%$ neither agree nor disagree with regard to whether pupils with ID should be educated in general classes, while $49.3 \%$ either agree or strongly agree. Additionally, 27.3\% hold a neutral attitude on whether pupils with ID should be removed from general classes less frequently, while $46.7 \%$ agree or strongly agree.

Consequently, the survey data analysis shows that SETs are in favour of the inclusion of pupils with ID, which will lead to their general inclusion in the school community and to reducing their social exclusion (Figure 1).

\subsection{Examination of questions per demographic characteristic of the sample}

In order to identify possible dependence of questions on people's demographics, average values are applied. The results are as follows:

In terms of past experience, there is statistically significant dependence on question (3): The special educator together with the general educator should adapt the general class according to the needs of the child with an $\operatorname{ID}(\mathrm{F}(2.145)=5.505, \mathrm{p}=0.005<0.05)$. From the sub-group's average sub-sample quiz values and from the multiple average value comparisons, it appears that teachers with extensive work experience tend to support the statement but only to a moderate degree. On the other hand, teachers with less work experience tend to support it to a higher degree.

In terms of education, statistically significant dependence is found in the case of two questions, 
Figure 1: Comparative presentation of mean values and standard deviations and distribution of frequencies and percentages of responses of SETs

\begin{tabular}{|c|c|c|c|c|c|c|c|c|}
\hline & Mean & SD & & $\begin{array}{l}\text { Absolutely } \\
\text { disagree }\end{array}$ & Disagree & $\begin{array}{c}\text { Neither agree } \\
\text { nor disagree }\end{array}$ & Agree & $\begin{array}{c}\text { Strongly } \\
\text { agree }\end{array}$ \\
\hline \multirow{2}{*}{$\begin{array}{l}\text { 1. Pupils with ID should be educated in general education classes with } \\
\text { non-disabled pupils. }\end{array}$} & & & $\mathrm{N}$ & 2 & 22 & 52 & 59 & 15 \\
\hline & 3.42 & .907 & $\%$ & $1.3 \%$ & $14.7 \%$ & $34.7 \%$ & $39.3 \%$ & $10.0 \%$ \\
\hline \multirow{2}{*}{$\begin{array}{l}\text { 2. Pupils with ID should be removed much less frequently from general } \\
\text { education classrooms, in order to be helped in the difficulties they encounter. }\end{array}$} & & & $\mathrm{N}$ & 6 & 33 & 41 & 57 & 13 \\
\hline & 3.25 & 1.024 & $\%$ & $4.0 \%$ & $22.0 \%$ & $27.3 \%$ & $38.0 \%$ & $8.7 \%$ \\
\hline \multirow{2}{*}{$\begin{array}{l}\text { 3. The SET with the general teacher should adapt the general education } \\
\text { classroom according to the needs of the child with ID. }\end{array}$} & & & $\mathrm{N}$ & 3 & 15 & 19 & 77 & 36 \\
\hline & 3.85 & .965 & $\%$ & $2.0 \%$ & $10.0 \%$ & $12.7 \%$ & $51.3 \%$ & $24.0 \%$ \\
\hline \multirow{2}{*}{$\begin{array}{l}\text { 4. Pupils with ID can be trained more effectively in general education } \\
\text { classrooms than in special education classrooms. }\end{array}$} & & & $\mathrm{N}$ & 8 & 33 & 62 & 35 & 12 \\
\hline & 3.07 & .994 & $\%$ & $5.3 \%$ & $22.0 \%$ & $41.3 \%$ & $23.3 \%$ & $8.0 \%$ \\
\hline \multirow[t]{2}{*}{ 5. Inclusive Education is considered suitable for children with ID. } & & & $\mathrm{N}$ & 3 & 9 & 40 & 76 & 22 \\
\hline & 3.70 & .865 & $\%$ & $2.0 \%$ & $6.0 \%$ & $26.7 \%$ & $50.7 \%$ & $14.7 \%$ \\
\hline \multirow{2}{*}{$\begin{array}{l}\text { 6. Inclusive Education cannot be applied to children with ID because they lack } \\
\text { academic and social skills. }\end{array}$} & & & $\mathrm{N}$ & 31 & 69 & 34 & 15 & 1 \\
\hline & 2.24 & .917 & $\%$ & $20.7 \%$ & $46.0 \%$ & $22.7 \%$ & $10.0 \%$ & $0.7 \%$ \\
\hline
\end{tabular}

- question (3): The special educator together with the general educator should adapt the general class according to the needs of the child with an ID $(\mathrm{F}(2.140)=5.219, \mathrm{p}=0.007<0.05)$. The tendency to support the statement is similar among all three groups, though the teachers who have gone through a training seminar, who declared the lowest score comparatively speaking, tend to support the statement more.

- question (6): Inclusive education cannot be applied to children with ID because they lack academic and social skills (F(2.140)=4.927, $\mathrm{p}=0.009<0.05)$. Teachers with postgraduate studies tended not to support the statement and disagreed with it to a greater extent.

In terms of work, there appeared to be a statistically significant dependence on the following questions (2): Pupils with an ID should be removed less frequently from the general education classes in order to be helped more in the difficulties they encounter ( $t(148)=-$ 2.070, $\mathrm{p}=0.040<0.05)$ and (5): Inclusive education is considered suitable for children with intellectual disability ( $\mathrm{t}(148)=-2.050$, $\mathrm{p}=0.042<0.05$ ). The tendency is to support these statements, but the difference is that people without work experience are more in support of them. 
Regarding the employment structure, there is a statistically significant dependence on question (2): Pupils with an ID should be removed less from the general education classes in order to help their difficulties $(\mathrm{F}(2.139)=2.618, \mathrm{p}=0.038<0.05)$. Regarding the above statement, teachers involved in the inclusion sector, and those in parallel support groups declared themselves mostly in agreement with the statement and those not in work mainly declared themselves in agreement, while the rest showed mostly disagreement.

A statistically significant relationship between the participants and the questions arises, concerning the number of pupils in the year 2017-2018: Questions (2): Pupils with ID should be less frequently removed from the general education classes in order to be helped to overcome the difficulties they face ( $\mathrm{r}=-, 175$ negative and weak), (4): Pupils with ID can be trained more effectively in general education classes than in special classes ( $\mathrm{r}=-, 170$ negative and weak), and (5): Inclusive education is considered suitable for children with ID ( $\mathrm{r}=-, 283$ negative and weak). Finally, statistically significant dependence was not shown in relation to age, the number of years of working with pupils with ID or the number of pupils in the school year 2016-2017.

\section{Discussion}

The majority of the limitations that people with SEND face are directly or indirectly related to negative attitudes toward them. A negative attitude toward any type of disability, and particularly ID, leads to discrimination (Corrigan, 2006; Corrigan \& Watson, 2002). Thus, many people with SEND are socially marginalised. According to the WHO report (2011, as cited in Mezquita-Hoyos, Sanchez-Monroy, Morales-Martinez, Lopez-Ramirez, \& Reyna-Gonzalez, 2018), people with SEND have no access to quality jobs and are poor and vulnerable in terms of health care. This unfavourable social situation is exacerbated for people with ID, who have also limited access to regular education programmes (Dávila, Naya \& Lauzurika, 2010; WHO, 2011, as cited in Mezquita-Hoyos et al., 2018).

International conventions (UNESCO, 1994; United Nations, 2006) have overwhelmingly supported the idea that pupils with ID should be included in mainstream formal educational settings and educated in general education classrooms (Sermier Dessemontet \& Bless, 2013). That is why, academic research aimed at achieving successful school inclusion and improving academic goal achievement for people with ID is expanding (Francis, Gross, Blue-Banning, Haines \& Turnbull, 2016). Many countries have already passed legislation and implemented practices that promote inclusive education for children with ID (Ferguson, 2008), and the topic has garnered a lot of academic attention in the last 40 years (Shogren, Palmer, Wehmeyer, Williams-Diehm, \& Little, 2011).

It is well known that teachers' attitudes toward pupils with SEND are a crucial factor in successful inclusive education (Carrington, 1999; Garrad et al., 2018). Any attitude- positive, negative and neutral- may affect the behaviour of teachers 
(Rosenzweig, 2009) and the education of the pupils with SEND. According to Mata and Clipa (2020) investigating teachers' attitudes helps teachers identify the most appropriate influence measures in order to establish relationships based on mutual valorisation and the promotion of equal participation opportunities. That is why the purpose of this quantitative survey was to study the attitudes of SETs towards the inclusion of children with ID in general education classes. From the statistical analysis of the data, it seems that the results are remarkable.

According to this research, the majority of SETs believe that the SET and general education teacher should collaborate to adapt the classroom to the needs of intellectually disabled pupils and that inclusion is appropriate for these pupils. There is agreement with the Weng, Walker, and Rosenblatt (2015) study, which found that SETs have positive attitudes toward including children with SEND in mainstream classrooms. Teachers are willing to make curriculum changes in order to include pupils with SEND in their classrooms.

Most SETs also accept the idea that inclusion can be applied to children with ID. This finding complements and strengthens the above view of the feasibility of inclusive education of children with ID in the general education classes. The international and Greek literature (Carrington, Berthelsen, Nickerson, Nicholson, Walker \& Meldrum, 2016; Freeman \& Alkin, 2000; Holahan \& Costenbader, 2000; Lappa \& Mantzikos, 2018; Mantzikos, Lappa, Siamanta \& Charoumenou, 2018; Mastropieri, Scruggs, Graetz, Norl, Gardizi, \& McDuffie, 2005; Oh-Young \& Filler, 2015; Ruijis \& Peetsma, 2009; Salend \& Garrick Duhaney, 1999; Smogorzewska, Szumski, \& Grygiel, 2018; Vaughn, Elbaum, Schumm \& Hughes, 1998; Vianello \& Lanfranchi 2015; Wehmeyer, Shogren, \& Kurth, 2021; Williamson, McLeskey, Hoppey \& Rentz, 2006) mention that the inclusive education is very beneficial for pupils with SEND. Some of these benefits are in the cognitive, social, emotional and behavioural field of human development.

However, this research has shown that there are a percentage of SETs who have ambiguous attitudes towards the inclusion of children with ID. Their attitudes seem to be neutral and sometimes neutral along with positive attitudes. In particular, neutral attitudes relate to whether pupils with ID could be trained in general education classes rather than in special classes. Their choice indicates that they believe that pupils with ID should be trained in special classes. On the other hand, their attitudes on whether pupils with ID should be educated in general education classes with non-disabled pupils and whether they should be removed less frequently from the general education classroom in order to be better helped to the difficulties they face were positive and neutral. Similar findings from other studies (Srivastava, De Boer \& Pijl, 2015; Srivastava, De Boer \& Pijl, 2017) are in agreement with the findings of this research.

In particular, Srivastava et al. (2015) examined teachers' attitudes and knowledge of four disabilities (Attention Deficit Hyperactivity Disorder, Dyslexia, Intellectual Disability and Autism). Their study sample consisted of 79 teachers from private and regular primary schools in Jaipur city. Their findings revealed that teachers had neutral attitudes towards inclusive education. Two years later these researchers (Srivastava et al., 
2017) conducted a similar study. Their study sample consisted of 115 regular primary school teachers. The results of their study revealed that teachers hold neutral attitudes towards inclusion of these pupils.

It seems that many teachers dealing with ID have low levels of knowledge pertaining to the topic. Many times, incomplete knowledge of ID has a rather negative impact, especially on the education of pupils with ID. If teachers do not receive repeated and meaningful training, it creates stress, anxiety and tension for both teachers and pupils in the classroom, especially when that classroom includes pupils with various disabilities (Ross-Hill, 2009). In general, resistance to inclusion is demonstrated by teachers who have limited education in ID. Unfortunately, general education teachers are often deprived of the experience and training needed for effective intervention in dealing with pupils with ID in their classrooms. This is because historically, SETs are the ones who have been involved in the education of these pupils (Dingle, Falvey, Givner \& Haager, 2004; Fuchs, 2010; Lohrmann \& Bambara, 2006).

However, teachers' attitudes can be changed by increasing their knowledge of inclusion in order to develop a better attitude that reflects how they think, feel, and behave, particularly in relation to inclusion. Teachers, who play critical roles in education, should have a thorough understanding of educational changes and acquire specific skills to improve their competency as teachers to all learners. When more pupils with emotional and behavioural difficulties and severe ID are included in general classrooms, more trainings, resources, and supports are required.

Professional development for mainstream teachers should be expanded to include pupils with ID in mainstream educational settings. Further enrichment and guidance are likely to improve mainstream teachers' ability to implement inclusion (Holdheide \& Reschly, 2008) leading to the formation of pro-inclusive attitudes (Cornoldi, Terreni, Scruggs, \& Mastropieri, 1998) and the academic success of inclusive pupils in mainstream educational settings (Evans, 1998). Every country's education stakeholders must consider developing teachers' attitudes toward inclusive education by enacting appropriate policies, providing adequate resources, and facilitating adequate pre-service and inservice training for teachers in order for them to understand and apply inclusive educational practices in their classrooms. The effort to achieve inclusive and quality education in all educational and social areas is one of the Sustainable Development Goals for 2030 that will help to combat inequality (Gallego-Ortega \& Rodríguez-Fuentes, 2021). The present study found that SETs are generally all in favour of the inclusion of pupils with ID, which will lead to their general inclusion in the school community and to a reduction in their social exclusion. That is why Bhatnagar and Das (2014) suggest that in order to create successful inclusion, teachers' attitudes and knowledge of inclusion should be maintained.

The present study has also highlighted the crucial role of some dependent variables- especially demographic factors- such as education, previous experience including work and employment structures. However, there are but few studies in the international literature that confirm the essential role of these variables. This study only 
confirms a single correlation. This correlation relates to experience; mainly that of ample past experience. In particular, research has shown that teachers who have extensive past experience are in favour of inclusive education and agree with the Alghazo and Naggar Gaad (2004), Alquraini (2012), Gilmore, Campbell, and Cuskelly (2003) surveys. These showed that past experience with pupils with ID played a key role in the attitudes of educators on inclusive education, as there was acceptance of the concept of inclusion of this group of pupils in their general education classrooms.

\subsection{Limitations of the study and implications for future research}

Two important limitations emerge in the present study. The first limitation concerns the sample size. The sample is not considered representative, as the researchers only aimed to collect data from a considerable number of SETs compared to the total number of SETs in Greece. This affects the generalisability of the study's results. The second limitation concerns data collection. Specifically, the researchers found it better to conduct an online survey to collect data for the purpose of this study. Although with developments in technology, web-based surveys have been increasingly used to collect data in recent years, it is possible for respondents to falsify their demographic information and use the internet to obtain information about the questions asked in the survey, which, in turn, undermines the reliability and accuracy of the results and the validity of conclusions drawn from the findings (Braunsberger, Wybenga \& Gates, 2007; Lefever, Dal \& Matthíasdóttir, 2007, as cited in Rakap, Balikci, \& Kalkan, 2018, p.179). Furthermore, online surveys might have a low response rate and high coverage error (i.e., the difference between the defined target population and who actually responded to the survey; Couper, 2000, as cited in Rakap et al., 2018, p. 179).

In this respect, we want to suggest some future directions to other researchers in this field. One possible avenue is to investigate the attitudes of mainstream teachers and SETs toward inclusion in the era of COVID-19 and the difficulties and barriers that these individuals have to face in these difficult times that humanity is experiencing. Another avenue is to investigate the strategies that promote the inclusion of these individuals in the general education classroom.

\section{Conclusion}

From the present study, it appears that hypotheses 1 and 3 are verified. In particular, SETs did have ambiguous attitudes (neutral along with positive attitudes) towards the education of children with ID. Question 2, which corresponds to the first research hypothesis, showed that SETs agree more strongly that pupils with such disability should be less frequently excluded from the general classroom to be helped in the difficulties they face. In a nutshell, they consider that the general education classrooms are quite useful for these pupils. On the other hand, with regard to the third research premise, teachers had a cautious attitude towards whether these pupils should be trained in general education classes. This reluctance is understood through their neutral attitude. It 
could also be the case that they consider that pupils with ID must also study in special classes according to the level of functionality they present. Finally, with regard to the second hypothesis, this does not seem to be verified. SETs have been positive about adapting the classroom according to the needs of these pupils, and that inclusive education can be implemented and positively benefit them. In conclusion, this research demonstrates that SETs seem to be in the favour of including pupils with ID in general education classes.

\section{Conflict of interest statement}

The authors declare no conflicts of interests.

\section{About the Authors}

Christina S. Lappa is an Academic Tutor-Advisor of Special Education at the Hellenic Open University (Patras, Greece) and at the University of Thessaly (Department of Special Education) (Volos, Greece). She has a Master of Science in School Psychology from L'Aquila University (Italy) and she has received her Ph.D. in Special Education from the Department of Special Education at the University of Thessaly (Volos, Greece). Furthermore, she has done her Post-Doctoral research on special education at the University of Thessaly. She has teaching experience in children and adults with special educational needs and disabilities in Greek public schools and universities. She has also published many research articles in the field of educational psychology and special education. Her research interests mainly focus on developmental disabilities, deaf and inclusion, special education, inclusive education, disability models, European and nonEuropean education policies, environmental education, differentiated instruction, applied behaviour analysis, social skills and conversational skills. ORCID: http://orcid.org/0000-0002-3960-2450

Constantinos N. Mantzikos is a special education teacher. He has received a B.Ed on special education from the Department of Special Education at the University of Thessaly (Volos, Greece). He has several years of teaching experience in children with special educational needs and disabilities in Greek public schools. Additionally, he has also published many research articles in the field of educational psychology and special education. His research interests mainly focus on developmental disabilities, deaf studies, deaf and inclusion, disability studies, inclusive education, special education, differentiated instruction, European and non-European education policies, home-school collaboration, disability models. ORCID: http://orcid.org/0000-0003-1698-5767

\section{References}

Ainscow, M. (2005). Developing inclusive education systems: what are the levers for change? Journal of Educational Change, 6(2), 109-124. https://doi.org/10.1007/s10833005-1298-4 
Alghazo, E., \& Naggar Gaad, E. (2004). General Education Teachers in the United Arab Emirates and Their Acceptance of the Inclusion of Students with Disabilities. British Journal of Special Education, 31(2), 94-99. https://doi.org/10.1111/j.0952$\underline{3383.2004 .00335 . x}$

Alquraini, T. A. (2012). Factors related to teachers' attitudes toward the inclusive education of students with severe intellectual disabilities in Riyadh, Saudi. Journal of Research in Special Educational Needs, 12(3), 170-182. https://doi.org/10.1111/j.1471-3802.2012.01248.x

American Association on Intellectual and Developmental Disabilities (n.d.). Definition of Intellectual Disability. Retrieved November 2021, from: https://cutt.ly/5YrI0mJ

Anagnostopoulou, A., \& Deropoulou-Derou, E. (2012). Attitudes of teachers (pre-school, primary and junior high school) of regular special and inclusive education towards learning disability. In: A. Zoniou-Sideri, E. Deropoulou-Derou, \& K. Papadopoulou. (eds), The research in special education, inclusive education and disability (Collective Volume B), (pp. 13-34). Athens: Pedio Publications (In Greek). Anderson, C. J. K., Klassen, R. M., \& Georgiou, G. K. (2007). Inclusion in Australia: What teachers say they need and what school psychologists can offer. School Psychology International, 28(2), 131-147. https://doi.org/10.1177/0143034307078086

Angelides, P., Stylianou, T., \& Gibbs, P. (2006). Preparing teachers for inclusive education in Cyprus. Teaching and Teacher Education, 22(4), 513-522. https://doi.org/10.1016/j.tate.2005.11.013

Arcangeli, L., Bacherini, A., Gaggioli, C., Sannipoli, M., \& Balboni, G. (2020). Attitudes of Mainstream and Special-Education Teachers toward Intellectual Disability in Italy: The Relevance of Being Teachers. International Journal of Environmental Research and Public Health, 17(19), 7325. https://doi.org/10.3390/ijerph17197325

Arnold, J., Silvester, J., Patterson, F., Robertson, I., Cooper, C., \& Burnes, B. (2005). Work psychology: understanding human behaviour in the workplace ( $\left.4^{\text {th }} \mathrm{Edn}\right)$. Harlow, UK: Financial Times Prentice Hall.

Avramidis, E., \& Kalyva, E. (2006). Research methods in Special Education: Theory and Applications. Athens, Greece: Papazisis Publications (In Greek).

Avramidis, E., \& Norwich, B. (2002). Teachers' attitudes towards integration / inclusion: a review of the literature. European Journal of Special Needs Education, 17(2), 129147. https://doi.org/10.1080/08856250210129056

Avramidis, E., Bayliss, P., \& Burden, R. (2000a). A Survey into Mainstream Teachers' Attitudes Towards the Inclusion of Children with Special Educational Needs in the Ordinary School in one Local Education Authority. Educational Psychology, 20(2), 191-211. https://doi.org/10.1080/713663717

Avramidis, E., Bayliss, P., \& Burden, R. (2000b). Student teachers' attitudes towards the inclusion of children with special educational needs in the ordinary school. Teaching and Teacher Education, 16(3), 277-293. https://doi.org/10.1016/S0742$\underline{051 X(99) 00062-1}$ 
Bhatnagar, N., \& Das, A. (2014). Attitudes of Secondary Regular School Teachers Toward Inclusive Education in New Delhi, India: A Qualitative Study. Exceptionality Education International, 24(2). https://doi.org/10.5206/eei.v24i2.7712

Boyer, K. K., Olson, J. R., \& Jackson, E. C. (2001). Electronic surveys: Advantages and disadvantages over traditional print surveys. Decision Line, 4-7. Retrieved June 2020, from: https://cutt.ly/iEmFj7j

Carrington, S. (1999). Inclusion needs a different school culture. International Journal of inclusive Education, 3(3), 257-268. https://doi.org/10.1080/136031199285039

Carrington, S., Berthelsen, D., Nickerson, J., Nicholson, J., Walker, S., \& Meldrum, K. (2016). Teachers' Experiences of Inclusion of Children with Developmental Disabilities across the Early Years of School. Journal of Psychologists and Counsellors in Schools, 26(2), 139-154. https://doi.org/10.1017/jgc.2016.19

Civitillo, S., De Moor, J. M. H., \& Vervloed, M. P. J. (2016). Pre-service teachers' beliefs about inclusive education in the Netherlands: An exploratory study. Support for Learning, 31(2), 104-121. https://doi.org/10.1111/1467-9604.12119

Cornoldi, C., Terreni, A., Scruggs, T. E., \& Mastropieri, M. A. (1998). Teacher Attitudes in Italy After Twenty Years of Inclusion. Remedial and Special Education, 19(6), 350356. https://doi.org/10.1177/074193259801900605

Corrigan, P. W. (2006). Mental Health Stigma as Social Attribution: Implications for Research Methods and Attitude Change. Clinical Psychology: Science and Practice, 7(1), 48-67. https://doi.org/10.1093/clipsy.7.1.48

Corrigan, P., \& Watson, A. M. (2002). Understanding the impact of stigma on people with mental illness. World Psychiatry, 1(1), 16-20.

Cullen, J. P., Gregory, J. L., \& Noto, L. A. (2010). The teacher attitudes toward inclusion scale (FATIS) technical report. 33rd Eastern Educational Research Association, Savannah, Georgia.

de Boer, A., Pijl, S. J., \& Minnaert, A. (2011). Regular primary schoolteachers' attitudes towards inclusive education: A review of the literature. International Journal of Inclusive Education, 15(3), 331-353. https://doi.org/10.1080/13603110903030089

Deropoulou-Derou, E. (2012). The evaluation of the course of legislative changes thirty years after the adoption of the first law on special education in Greece. In: A. Zoniou-Sideri, E. Deropoulou-Derou, \& A. Vlachou-Balafouti. (eds), Disability and Educational Policy. (pp. 123-151). Athens: Pedio Publications (In Greek).

Dingle, M., Falvey, M. A., Givner, C. C., \& Haager, D. (2004). Essential special and general education teacher competencies for preparing teachers for inclusive settings. Issues in Teacher Education, 13(1), 35-50.

Drakotou, A., \& Zoniou-Sideri, A. (2016). First and second grade "support teachers" opinions and experiences regarding the institution of "support teacher". In: A. Zoniou-Sideri, E. Deropoulou-Derou, \& K. Papadopoulou. (Eds), Research in Special Education, inclusive education and disability (Collective Volume E), (pp.11-27). Athens: Pedio Publications (In Greek). 
European Agency for Special Needs and Inclusive Education. (2021). Greek Legislation and policy Retrieved June 2021, from: https://cutt.ly/2EmFTIW

Evans, L. (1998). Teacher Morale, Job Satisfaction and Motivation. London, UK: Paul Chapman.

Ferguson, D. L. (2008). International trends in inclusive education: the continuing challenge to teach each one and everyone. European Journal of Special Needs Education, 23(2), 109-120. https://doi.org/10.1080/08856250801946236

Francis, G. L., Gross, J. M. S., Blue-Banning, M., Haines, S., \& Turnbull, A. P. (2016). School Principals and Parents Who Achieve Optimum Results: Lessons Learned from Six North American Schools that have Implemented Inclusive Practices. Revista Latinoamericana de Inclusión Educativa, 10(1), 43-60. Retrieved June 2020, from: http://www.rinace.net/rlei/numeros/vol10-num1/art2.pdf

Freeman, S. F. N., \& Alkin, M. C. (2000). Academic and social attainments of children with mental retardation in general education and special education settings. Remedial and Special Education, 21(1), 3-26. https://doi.org/10.1177/074193250002100102

Fricker, R. D., \& Shonlau, M. (2002). Advantages and disadvantages of Internet research surveys: Evidence from the literature. Field Methods, 14(2), 347-367. https://doi.org/10.1177/152582202237725

Fuchs, W. W. (2010). Examining teachers' perceived barriers associated with inclusion. STRATE Journal, 19, 35.

Gallego-Ortega, J., \& Rodríguez-Fuentes, A. (2021). Teaching Attitudes towards Students with Disabilities. Mathematics, 9(14), 1637. https://doi.org/10.3390/math9141637

Garrad, T. A., Rayner, C., \& Pedersen, S. (2018). Attitudes of Australian primary school teachers towards the inclusion of students with autism spectrum disorders. Journal of Research in Special Educational Need, 19(1), 58-67. https://doi.org/10.1111/1471$\underline{3802.12424}$

Gilmore, L., Campbell, J., \& Cuskelly, M. (2003). Developmental Expectations, Personality Stereotypes, and Attitudes Towards Inclusive Education: Community and teacher views of Down syndrome. International Journal of Disability, Development and Education, 50(1), 65-76. https://doi.org/10.1080/1034912032000053340

Hastings, R. P. \& Oakford, S. (2003). Student teachers' attitudes toward the inclusion of children with special needs. Educational Psychology, 23(1), 87-94. https://doi.org/10.1080/01443410303223

Hettiarachchi, S., \& Das, A. (2014). Perceptions of "inclusion" and perceived preparedness among school teachers in Sri Lanka. Teaching and Teacher Education, 43, 143-153. https://doi.org/10.1016/j.tate.2014.07.003

Holahan, A., \& Costenbader, V. (2000). A comparison of developmental gains for preschool children with disabilities in inclusive and self-contained classrooms. Topics in Early Childhood Special Education, 20(4), 224-235. https://doi.org/10.1177/027112140002000403 
Holdheide, R. L. \& Reschly, J. D. (2008). Teacher Preparation to Deliver Inclusive Service to Students with Disabilities (National Comprehensive Center for Teacher Quality Connection, Issue Paper, 1-28). Washington, DC: National Comprehensive Center for Teacher Quality. Retrieved June 2020, from: https://eric.ed.gov/?id=ED543818

Hughes, C. E., \& Murawski, W. W. (2001). Lessons from Another Field: Applying Coteaching Strategies to Gifted Education. Gifted Child Quarterly, 45(3), 195-204. https://doi.org/10.1177/001698620104500304

Humphrey, N., \& Lewis, S. (2008). 'Make me normal': the views and experiences of pupils on the autistic spectrum in mainstream secondary schools. Autism: An International Journal of Research and Practice, 12(1), 23-47. https://doi.org/10.1177/1362361307085267

Kamtsios, S., \& Lolis, Th. (2016). Do Greek teachers experience professional burnout? The role of demographic characteristics and daily stressful events. Journal of Research in Education and Training, 9(1), 40-87. http://dx.doi.org/10.12681/jret.10277 (In Greek).

Khochen, M., \& Radford, J. (2012). Attitudes of teachers and headteachers towards inclusion in Lebanon. International Journal of Inclusive Education, 16(2), 139-153. https://doi.org/10.1080/13603111003671665

Kontoleon, G. A., \& Deropoulou-Derou, E. (2013). Secondary education teachers' views and experiences towards the role of support teachers of students with disabilities inside the regular classrooms in mainstream schools. In: A. Zoniou-Sideri, E. Deropoulou-Derou, \& K. Papadopoulou. (Eds), Research in Special Education, inclusive education and disability (Collective Volume C), (pp.11-34). Athens: Pedio Publications (In Greek).

Krischler, M., \& Pit-ten Cate, I. (2019). Pre- and In-Service Teachers' Attitudes Toward Students with Learning Difficulties and Challenging Behavior. Frontiers In Psychology, 10, 1-10. https://doi.org/10.3389/fpsyg.2019.00327

Lampadari, I., \& Gkaravelas, K. (2018). The inclusion of students with Autistic Spectrum Disorder: Experience, knowledge, and attitudes of Secondary Education Teachers. Theory and Research in the Sciences of Education, 29, 7-32. (In Greek)

Lappa, C., \& Mantzikos, C. (2018). The issue of educating children in the autism spectrum in Greece, based on the knowledge/perceptions and attitudes of teachers: A literature review. Hellenic Journal of Research in Education, 7(1), 44-63. http://dx.doi.org/10.12681/hire.16161 (In Greek).

Lappa, C., Mantzikos, C., \& Paraskevopoulos, S. (2019). The contribution of Environmental Education in the education of children with disabilities and/or special educational needs: Views of teachers. Hellenic Journal of Research in Education, 8(1), 1-16. http://dx.doi.org/10.12681/hjre.19473 (In Greek)

Law 1143. (1981). Special Education, Specialised Vocational Training, Employment and Social Care of diverging individuals from normalisation and other Educational Provisions. Government Gazette 1(80), 787-798. (In Greek). 
Lohrmann, S., \& Bambara, L. M. (2006). Elementary education teachers' beliefs about essential support needed to successfully include students with developmental disabilities who engage in challenging behaviors. Research $\mathcal{E}$ Practice for Persons with Severe Disabilities, 31, 157-173. doi:10.1177/154079690603100208

Loreman, T., Sharma, U., \& Forlin, C. (2013). Do Pre-service Teachers Feel Ready to Teach in Inclusive Classrooms? A Four Country Study of Teaching Self-efficacy. Australian Journal of Teacher Education, 38(1), 27-44. http://dx.doi.org/10.14221/ajte.2013v38n1.10

Luckasson, R., Borthwick-Duffy, S., Buntinx, W.H.E., Coulter, D.L., Craig, E.M., \& Reeve, A. (2002). Mental Retardation: Definition, Classification, and Systems of Support $\left(10^{\text {th }}\right.$ Edn). Washington, DC: American Association on Mental Retardation.

Male, D. B. (2011). The impact of a professional development programme on teachers' attitudes towards inclusion. Support for Learning, 26(4), 182-186. https://doi.org/10.1111/j.1467-9604.2011.01500.x

Mantzikos, C., Lappa, C., Siamanta, V., \& Charoumenou, Z. (2018). The Evaluation of the Structure of Parallel Support by Parents of Children with Autism Spectrum Conditions. Preschool and Primary Education, 6(2), 144-162. http://dx.doi.org/10.12681/ppej.15889 (In Greek)

Mastropieri, M.A., Scruggs, T.E., Graetz, J., Norl, J., Gardizi, W., \& McDuffie, K. (2005). Case studies in coteaching in the content areas: Successes, failures and challenges. Intervention in School and Clinic, 40, 260-270. https://doi.org/10.1177/10534512050400050201

Mata, L., \& Clipa, O. (2020). Inclusive Education and In-service Teachers' Attitudes. Revista Românească pentru Educaţie Multidimensională, 12(1), 135-149. https://doi.org/10.18662/rrem/204

Mavropoulou, S., \& Padeliadu, S. (2000). Greek teachers' perception of autism and implications for educational practice: A preliminary analysis. Autism, 4(2), 173183. https://doi.org/10.1177/1362361300004002005

Medlin, C., Subroto, R., \& Theong, H. C. (2005). Using a World Wide Web Survey to Obtain Marketing Information for Business Decisions: A Comparison with Mail Surveys. Singapore: Singapore Department of Statistics.

Memisevic, H. \& Hodzic, S. (2011). Teachers' attitudes toward inclusion of students with intellectual disability in Bosnia and Herzegovina. International Journal of Inclusive Education, 15(7), 699-710. https://doi.org/10.1080/13603110903184001

Metha, R., \& Sivadas, E. (1995). Comparing response rates and response content in mail versus electronic mail surveys. Journal of the Market Research Society, 37(4), 429-439.

Mezquita-Hoyos, Y. N., Sanchez-Monroy, M. H., Morales-Martinez, G. E., LopezRamirez, E. O., \& Reyna-Gonzalez, M. R. (2018). Regular and special education Mexican teachers' attitudes toward school inclusion and disability. European Journal of Educational Research, 7(3), 421-430. https://doi.org/10.12973/eu-jer.7.3.421 
Moberg, S. (2003). Education for all in the north and the south: teachers' attitudes toward inclusive education in Finland and Zambia. Education and Training in Developmental Disabilities, 38(4), 417-428. https://www.jstor.org/stable/23879917

Novakos, I. 2018. The views of teachers about the institution of Parallel Support in Greece. Theory and Research in the Sciences of Education, 26, 7-32. Retrieved August 2021, from: http://periodiko.inpatra.gr/issue/issue26/ (In Greek).

O'Leary, L., Henderson, A., Jacobs, M., \& Copper, S. A. (2016). Children with intellectual disabilities and children with autism in Scottish schools. IASSIDD World Congress: Global Partnerships: Enhancing Research, Policy and Practice, Melbourne, Australia, 15-19 August.

Oh-Young, C., \& Filler, J. (2015). A meta-analysis of the effects of placement on academic and social skill outcome measures of students with disabilities. Research in Developmental Disabilities, 47, 80-92. https://doi.org/10.1016/j.ridd.2015.08.014

Ojok, P., \& Wormnæs, S. (2013). Inclusion of pupils with intellectual disabilities: primary school teachers' attitudes and willingness in a rural area in Uganda. International Journal of Inclusive Education, 17(9), 1003-1021. https://doi.org/10.1080/13603116.2012.728251

Pantić, N., \& Florian, L. (2015). Developing teachers as agents of inclusion and social justice. Education Inquiry, 6(3), 333-351. https://doi.org/10.3402/edui.v6.27311

Parsons, S. (2014). 'Why are we an ignored group?' Mainstream educational experiences and current life satisfaction of adults on the autism spectrum from an online survey. International Journal of Inclusive Education, 19(4), 397-421. https://doi.org/10.1080/13603116.2014.935814

Parsons, S., \& Lewis, A. (2010). The home education of children with special needs or disabilities in the UK: views of parents from an online survey. International Journal of Inclusive Education, 14(1), 67-86. https://doi.org/10.1080/13603110802504135

Parsons, S., Lewis, A., \& Ellins, J. (2009). The views and experiences of parents of children with autistic spectrum disorder about educational provision: comparisons with parents of children with other disabilities from an online survey. European Journal of Special Needs Education, 24(1), 37-58. https://doi.org/10.1080/08856250802596790

Pervin, M. (2016). Attitudes towards inclusion of pupils with autism spectrum disorder (ASD): A survey of regular primary school teachers in Bangladesh. Unpublished Master's Thesis, University of Oslo, Norway.

Rakap, S., Balikci, S., \& Kalkan, S. (2018). Teachers' knowledge about autism spectrum disorder: The case of Turkey. Turkish Journal of Education, 7(4), 169-185.

Rose, R. (2001). Primary School Teacher Perceptions of the Conditions Required to Include Pupils with Special Educational Needs. Educational Review, 53(2), 147-156. https://doi.org/10.1080/00131910120055570

Rosenzweig, K. (2009). Are Today's General Education Teachers Prepared to Meet the Needs of Their Inclusive Students? Northeastern Educational Research Association (NERA) Annual Conference. Retrieved June 2021, from: https://cutt.ly/KEmF08k 
Ross-Hill, R. (2009). Teacher attitude towards inclusion practices and special needs students. Journal of Research in Special Educational Needs, 9(3), 188-198. https://doi.org/10.1111/j.1471-3802.2009.01135.x

Ruijis, N. M., \& Peetsma, T. T. D. (2009). Effects of inclusion on students with and without special educational needs reviewed. Educational Research Review, 4(2), 67-79. https://doi.org/10.1016/j.edurev.2009.02.002

Salend, S. J., \& Garrick Duhaney, L. M. (1999). The Impact of Inclusion on Students with and Without Disabilities and Their Educators. Remedial and Special Education, 20 (2), 114-126. https://doi.org/10.1177/074193259902000209

Sarris, D., Riga, P., \& Zaragas, H. (2018). School teachers' attitudes toward inclusive education in Greece. European Journal of Special Education Research, 3(3), 182-194. http://dx.doi.org/10.46827/ejse.v0i0.1668

Schalock, R. L., Luckasson, R., \& Tassé, M. (2021). Intellectual Disability: Definition, Diagnosis, Classification, and Systems of Supports (12 ${ }^{\text {th }}$ Edn). Maryland, US: American Association on Intellectual and Developmental Disabilities.

Sermier Dessemontet, S.R., \& Bless, G. (2013). The impact of including children with intellectual disability in general education classrooms on the academic achievement of their low-, average-, and high-achieving peers. Journal of Intellectual $\mathcal{E} \quad$ Developmental Disability, 38(1), 23-30. https://doi.org/10.3109/13668250.2012.757589

Sharma, U., \& Nuttal, A. (2016). The impact of training on pre-service teacher attitudes, concerns, and efficacy towards inclusion. Asia-Pacific Journal of Teacher Education, 44 (2), 142-155. https://doi.org/10.1080/1359866X.2015.1081672

Shogren, K. A., Palmer, S. B., Wehmeyer, M. L., Williams-Diehm, K., \& Little, T. D. (2011). Effect of Intervention with the Self-Determined Learning Model of Instruction on Access and Goal Attainment. Remedial and Special Education, 33(5), 320-330. https://doi.org/10.1177/0741932511410072

Slee, R. (2010). Political economy, inclusive education and teacher education. In: C. Forlin (ed), Teacher Education for Inclusion: Changing Paradigms and Innovative Approaches (pp. 13-22). New York, NY: Routledge.

Slee, R. (2011). Inclusive education and and education reform in the new era. In: A. Zoniou-Sideri, \& I. Spandagou (Eds), Education and Blindness: Modern trends and perspectives (pp. 40-56). Athens: Pedio Publications (In Greek).

Smogorzewska, J., Szumski, G., \& Grygiel, P. (2018). Theory of mind development in school environment: A case of children with mild intellectual disability learning in inclusive and special education classrooms. Journal of Applied Research in Intellectual Disabilities, 32(5), 1241-1254. https://doi.org/10.1111/jar.12616

Soulis, S. P. (2008). A school for all. From research to practice. The pedagogy of inclusion (Volume B). Athens, Greece: Gutenberg Publications (In Greek).

Srivastava, M., de Boer, A. A., \& Pijl, S. J. (2015). Know how to teach me... Evaluating the effects of an in-service training program for regular school teachers toward 
inclusive education. International Journal of School E Educational Psychology, 3(4), 219-230. https://doi.org/10.1080/21683603.2015.1064841

Srivastava, M., de Boer, A. A., \& Pijl, S. J. (2017). Preparing for the inclusive classroom: changing teachers' attitudes and knowledge. Teacher Development, 21(4), 561-579. https://doi.org/10.1080/13664530.2017.1279681

Stasinos, D. P. (2016). Special Education 2020 plus: For inclusive or total education in the new digital school with digital champions. Athens: Papazisis Publications (In Greek).

Subban, P., \& Sharma, U. (2006). Primary school teachers' perceptions of inclusive education in Victoria, Australia. International Journal of Special Education, 21(1), 4252.

Takala, M., Pirttimaa, R., \& Törmänen, M. (2009). Inclusive special education: the role of special education teachers in Finland. British Journal of Special Education, 36(3), 162172. https://doi.org/10.1111/j.1467-8578.2009.00432.x

UNESCO (1994). The Salamanca Statement and Framework for Action on Special Needs Education. Salamanca: UNESCO.

United Nations (2006). United Nations Convention on the Rights of Persons with Disabilities. Retrieved June 2020, from: https://cutt.ly/yEmDHiw

Van Selm, M., \& Jankowski, N. (2006). Conducting Online Surveys. Quality \& Quantity: International Journal of Methodology, 40(3), 435-456.

Varcoe, L., \& Boyle, C. (2014). Pre-service primary teachers' attitudes towards inclusive education. Educational Psychology, 34(3), 323-337. https://doi.org/10.1080/01443410.2013.785061

Vaughn, S., Elbaum, B. E., Schumm, J. S., \& Hughes, M. T. (1998). Social outcomes for students with and without learning disabilities in inclusive classrooms. Journal of Learning Disabilities, 31(5), 428-436. https://doi.org/10.1177/002221949803100502

Vernier, K. M. (2012). The effects of training on teachers' perceptions of inclusion of students with intellectual disabilities. Unpublished Master's Thesis, Utah State University.

Vianello, R., \& Lanfranchi. S. (2015). Looking beyond the Alibi That Not Everything Function Perfectly in Italy: A Response to Anastasiou, Kauffman and Di Nuovo. European Journal of Special Needs Education, 30(4), 454-456. https://doi.org/10.1080/08856257.2015.1079032

Warren, J., Soukakou, E., Forster, J., Ng, L., \& Nteropoulou-Nterou, E. (2021). Small Steps: The Inclusion of Young Children with Disabilities in Australia, Greece, and Malaysia. Australasian Journal of Special and Inclusive Education, 45(2), 164-177. https://doi.org/10.1017/jsi.2021.13

Wehmeyer, M. L., Shogren, K. A., \& Kurth, J. (2021). The State of Inclusion with Students with Intellectual and Developmental Disabilities in the United States. Journal of Policy and Practice in Intellectual Disabilities, 18(1), 36-43. https://doi.org/10.1111/jppi.12332

Weng, C. S., Walker, Z. M., \& Rosenblatt, K. (2015). Special Education Teachers' Attitudes toward Including Students with SEN in Mainstream Primary Schools in Singapore. Asia Pacific Journal of Developmental Differences, 2(1), 63-78. 
Wilkerson, S. (2012). Assessing teacher attitude towards the inclusion of students with autism. Unpublished Doctoral Dissertation, University of Louisville, USA.

Williamson, P., McLeskey, J., Hoppey, D., \& Rentz, T. (2006). Educating students with mental retardation in General Education Classrooms. Exceptional Children, 72(3), 347-361. https://doi.org/10.1177/001440290607200306

Winter, S., \& Bunn, H. (2019). Work to be done? A survey of educational psychologists' contribution to special schools for profound and multiple learning difficulties. British Journal of Special Education, 45(4), 1-23. https://doi.org/10.1111/1467$\underline{8578.12252}$

Wright, K, B. (2005). Researching Internet-Based Populations: Advantages and Disadvantages of Online Survey Research, Online Questionnaire Authoring Software Packages, and Web Survey Services. Journal of Computer-Mediated Communication, 10(3). Retrieved June 2021, from: https://cutt.ly/wEmGaIj

Yunkis, C. (2015). Attitudes of Pre-service Teachers Toward Inclusion for Students Who Are Deaf. Deafness $\mathcal{E}$ Education International, 17(4), 183-193. https://doi.org/10.1179/1557069X15Y.0000000003

Zhang, Y. (1999). Using the Internet for Survey Research: A Case Study. Journal of American Society for Information Science, 51(1), 57-68. Retrieved June 2021, from: https://cutt.ly/JEmGv4x 
Creative Commons licensing terms

Authors will retain the copyright of their published articles agreeing that a Creative Commons Attribution 4.0 International License (CC BY 4.0) terms will be applied to their work. Under the terms of this license, no permission is required from the author(s) or publisher for members of the community to copy, distribute, transmit or adapt the article content, providing a proper, prominent and unambiguous attribution to the authors in a manner that makes clear that the materials are being reused under permission of a Creative Commons License. Views, opinions and conclusions expressed in this research article are views, opinions and conclusions of the author(s). Open Access Publishing Group and European Journal of Special Education Research shal not be responsible or answerable for any loss, damage or liability caused in relation to/arising out of conflict of interests, copyright violations and inappropriate or inaccurate use of any kind content related or integrated on the research work. All the published works are meeting the Open Access Publishing requirements and can be freely accessed, shared, modified, distributed and used in educational, commercial and non-commercial purposes under a Creative Commons Attribution 4.0 International License (CC BY 4.0). 